\title{
A few single crystal zircon ages from the Padeş suite orthogneisses (Southern Carpathians, Romania)
}

\author{
Ioan BALINTONI ${ }^{*}$, Constantin BALICA ${ }^{1}$, Monica CLIVETI'1, Li-Qiu LI², \\ Horst Peter HANN3, Fukun CHEN² \\ ${ }^{1}$ Department of Geology, "Babeş-Bolyai” University, 1 Kogălniceanu, 400084 Cluj Napoca, Romania \\ ${ }^{2}$ Institute of Geology and Geophysics, Chinese Academy of Sciences, P.O. Box 9825, Beijing, 100029, China \\ ${ }^{3}$ Institut für Geowissenschaften, Universität Tübingen, 72076 Tübingen, Germany
}

Received July 2005; accepted March 2006

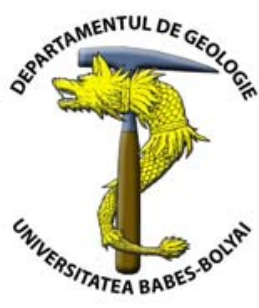

ABSTRACT. The Padeş suite from the Poiana Ruscă Mountains is a component of the Padeş Paleozoic terrane. The Padeş terrane evolved as an island arc between the Cadomian Sebeş-Lotru and Făgăraş terranes, the main parts of the Getic crystalline in the Southern Carpathians. Evaporated single zircon grains offered $394 \pm 20 \mathrm{Ma}, 546 \pm 20$ $\mathrm{Ma}, 655 \pm 19 \mathrm{Ma}, 1305 \pm 17 \mathrm{Ma}$, and $1538 \pm 17 \mathrm{Ma}$ ages. The $394 \mathrm{Ma}$ age has been interpreted as an early Variscan collision age, $546 \mathrm{Ma}$ as the protolith age and the other ages as signifying Cadomian and Saharan detrital zircons. Similar to the terranes in the Apuseni Mountains, the Padeş terrane has a North African-Gondwanan provenance.

Key words: Southern Carpathians, Padeş terrane, zircon ages

\section{INTRODUCTION}

Due to very divergent models proposed during the last decade, regarding the Poiana Ruscă Mountains crystalline (e.g. Kräutner, 1996; Balintoni, 1997; Mureşan, 2003) we will join in the present paper with the ideas presented by Balintoni (1997), based on the paper of Balintoni and Iancu (1996). According to these authors, the Padeş suite represents the uppermost lithotectonic unit of the Getic crystalline (from an Alpine point of view), although the preAlpine tectonic relationship with the Fagaraş suite, also present in the Poiana Ruscă Mountains, is obvious (Fig. 1). As a possible continuation of the Tulghes suite from the Eastern Carpathians, the Padeş suite is a part of a Variscan suture between the Sebeş-Lotru terrane and Făgăraş terrane. In a Variscan model of the Southern Carpathians Getic crystalline, the following Paleozoic terranes can be separated: Sebeş-Lotru, Leaota, Făgăraş, Bocşiţa-Drimoxa and Padeş (Fig. 1). The Getic crystalline has an Alpine tectonic relationship with the Danubian crystalline. Thus, the Padeş suite is regarded as an island arc terrane characterized by intense acidic volcanism. Thick bodies of meta-rhyolites are known in the northern part of Poiana Ruscă Mountains, near Deva town and north of Mureş River, in the Rapolt Massif (Bordea et al., 1978; Lupu et al., 1982). In this paper we present single zircon evaporation ages performed on meta-rhyolites of Padeş suite.

\section{SAMPLE DESCRIPTION}

The sample \#182 was collected from Rapolt massif, north of Mureş valley, near the Rapolțel village. The sample \#183 was picked up west of Deva town, near Vețel village.
Both samples contain the same minerals: quartz, plagioclase, K-feldspar, muscovite, epidote, opaque minerals, apatite, zircon and small amounts of stilpnomelane. The sample \#183 is richer in muscovite and epidote than the sample \#182. The rocks are foliated with quartz and feldspar porphyroblasts. According to the mineralogy and structure presented here, the samples represent metarhyolites.

\section{ANALYTICAL METHODS}

Measurement on isotopic ratios were performed in the Laboratory of Radiogenic Isotope Geochemistry, Institute of Geology and Geophysics, Chinese Academy of Sciences, Beijing, using an IsoProbe-T thermal ionization mass spectrometer manufactured by the GV company. The IsoProbe- $\mathrm{T}$ is equipped with 9 Faraday cups, 1 Daly receiver and 7 ion-counters. The technique used for zircon evaporation is similar to that developed by Kober (1986). Pb isotopes $\left({ }^{204} \mathrm{~Pb},{ }^{206} \mathrm{~Pb},{ }^{207} \mathrm{~Pb}\right.$, and $\left.{ }^{208} \mathrm{~Pb}\right)$ were statically measured using four ion-counters with an 8-secondintergration.

Calculation of ${ }^{207} \mathrm{~Pb} /{ }^{206} \mathrm{~Pb}$ ages is based on mean values of all measurements and uncertainties are given at $2 \sigma$ standard deviation. Age for several zircons from the same sample is given as weighted average and its $2 \sigma$ error propagated from the assigned errors $(2 \sigma$ internal error; Ludwig, 2001).

$\mathrm{Pb}-\mathrm{Pb}$ analytical data were evaluated with $2 \sigma$ standard error using the PbDAT program (Ludwig, 1988). Probability/density plots in diagrams were done using the Isoplot program (Ludwig, 2001). More details on analytical techniques are given in Chen et al. (2000). 


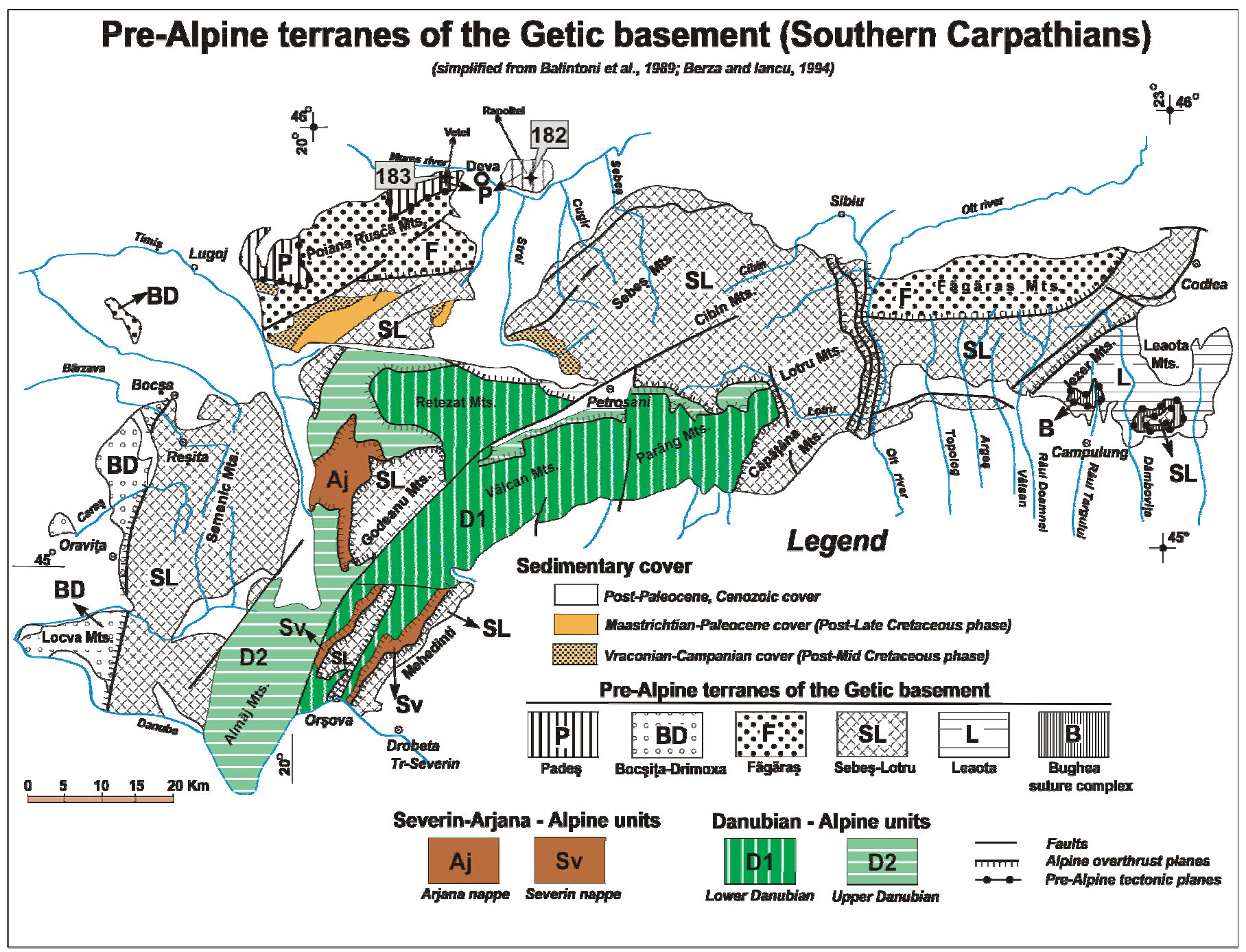

Fig. 1. Sketch of the Southern Carpathians showing the main pre-Alpine and Alpine tectonic units and sampling locations. Compilation based on Balintoni et al. (1989), Balintoni (1997), Berza et al. (1994), and Berza and Iancu (1994).

\section{ANALYTICAL RESULTS}

Two crystals evaporated from samples 182 (Rapolțel) and 183 (Vețel), gave a cluster of $394 \pm 17 \mathrm{Ma}$ (Fig. 2, Table 1). One zircon crystal evaporated out of sample 183 (Vețel) furnished an age around $546 \pm 20 \mathrm{Ma}$ (Fig. 3).
Another crystal of sample 183 (Vețel) offered a cluster at $655 \pm 19$ Ma (Fig. 4). Finally, one evaporated zircon crystal from sample 182 (Rapolțel) yielded two clusters at $1305 \pm 17$ Ma and $1538 \pm 17 \mathrm{Ma}$, respectively (Fig. 5). All these ages have geological significance.

Table 1. Zircon evaporation data for samples of the Padeş sequence. Calculation of ${ }^{207} \mathrm{~Pb} /{ }^{206} \mathrm{~Pb}$ ages is based on mean values of all or selected measurements and uncertainties are given at $2 \sigma$ standard deviation

\begin{tabular}{lcccc}
\hline \multicolumn{1}{c}{ Sample } & No of grains & No. of ratios & Mean value of ${ }^{207} \mathrm{~Pb} /{ }^{206} \mathrm{~Pb}$ ratios & ${ }^{207} \mathrm{~Pb} /{ }^{206} \mathrm{~Pb}$ age $(\mathrm{Ma})$ \\
\hline 182-I \& 183-III & 2 & 39 & 0.054556 & $394 \pm 17$ \\
183-I & 1 & 32 & 0.058435 & $546 \pm 20$ \\
183 -II & 1 & 26 & 0.061449 & $655 \pm 19$ \\
182 -II & 1 & 9 & 0.084524 & $1305 \pm 17$ \\
& & 9 & 0.095518 & $1538 \pm 17$ \\
\hline
\end{tabular}

\section{DISCUSSION}

Ages provided by the Padeş meta-rhyolites strike similar with the ages provided by the Baia de Arieş, Someş and Păiuşeni sequences rocks from the Apuseni Mountains (Balintoni et al., $2007 \mathrm{a}, \mathrm{b}, \mathrm{c}$ ).

The $394 \mathrm{Ma}$ age can be viewed as a recrystallization related to early Variscan collision. This age coincides with that one of the Arieş migmatites leucosome.

The $546 \mathrm{Ma}$ is the protolith age of Baia de Atieş orthogneisses. This is also the possible protolith age of Padeş meta-rhyolites.
Again the $655 \mathrm{Ma}$ age is identical with the detrital zircon age $(656 \mathrm{Ma})$ in the Păiuşeni metapelite. A metasandstone from the Someş sequence contains detrital zircons of 722 Ma. Consequently the $655 \mathrm{Ma}$ age can be admitted as a detrital zircon age. The $546 \mathrm{Ma}$ and $655 \mathrm{Ma}$ ages point to the Cadomian orogeny as the genetic environment of the Padeş sequence. Ages around $1305 \mathrm{Ma}$ and $1538 \mathrm{Ma}$ are also known from the Baia de Arieş sequence rocks. They have been interpreted as signaling Saharan detrital zircon ages. Therefore we suppose a Saharan zircon presence in the Padeş sequence meta-rhyolites, too. 


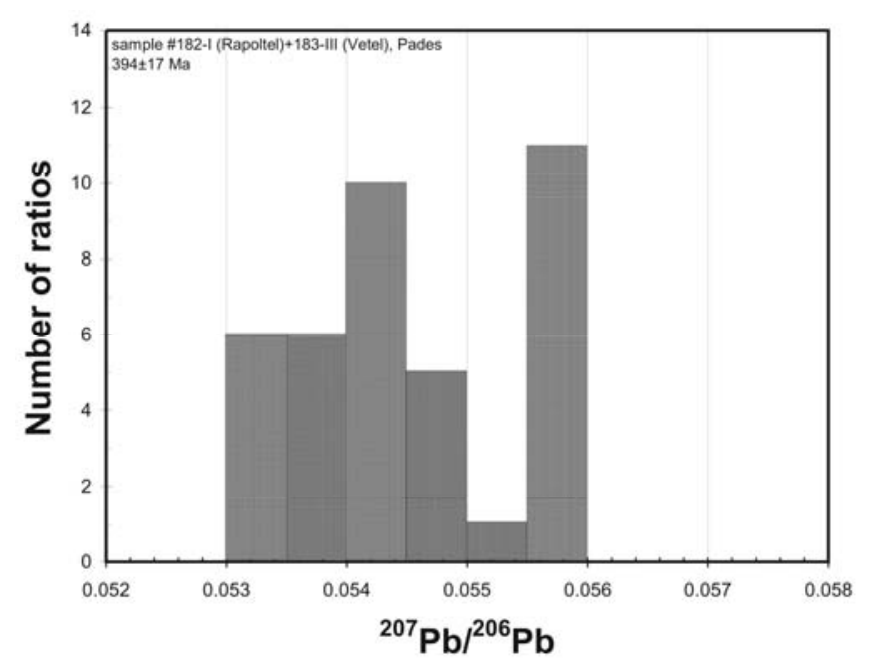

Fig. 2. Frequency diagram of two evaporated zircon grains out of sample 182-I (Rapolțel) and 183-III (Vețel) which gave a mean ${ }^{207} \mathrm{~Pb} /{ }^{206} \mathrm{~Pb}$ age of $394 \pm 17 \mathrm{Ma}$.

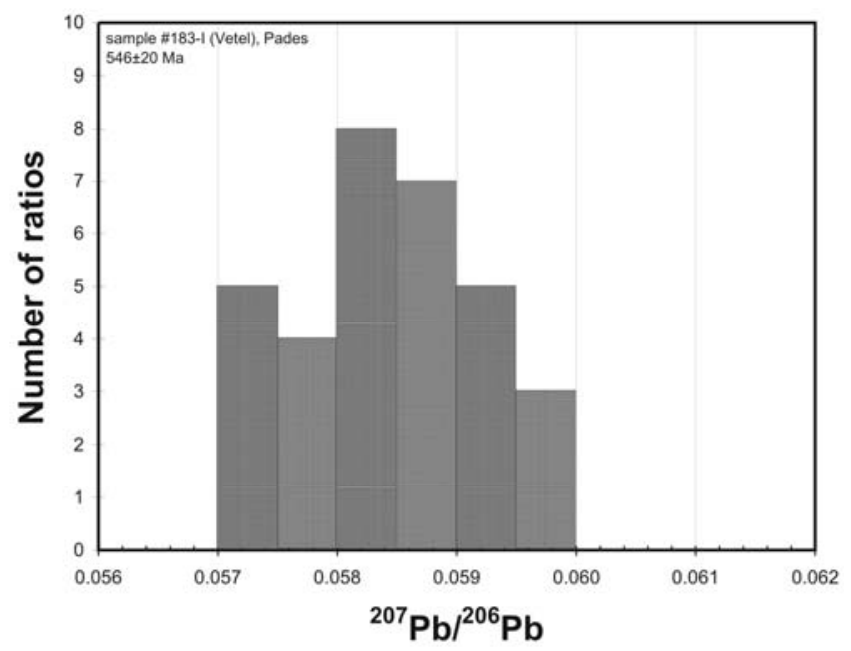

Fig. 3. Frequency diagram of one evaporated zircon grain out of sample 183-I (Vețel) which gave a mean ${ }^{207} \mathrm{~Pb} /{ }^{206} \mathrm{~Pb}$ age of $546 \pm 20 \mathrm{Ma}$.

\section{CONCLUSIONS}

The data presented here are insufficient in order to present a strong conclusive model regarding the Padeş sequence evolution. However, we can say that the Padeş sequence, as the constitutive material of the Padeş terrane, suggests a Cadomian, peri-Gondwanan origin. It probably collided with other Carpathian terranes around $400 \mathrm{Ma}$. If the Padeş sequence represents a prolongation of the Tulgheş sequence from the Eastern Carpathians, then the Padeş terrane has been situated between the Sebeş-Lotru and Făgăraş terranes as the main constituents of the Southern Carpathians Getic crystalline.

We mention that Pană et al. (2002) communicated lowermost Ordovician-Cambrian $\mathrm{U} / \mathrm{Pb}$ ages from the Tulgheş sequence meta-acidic rocks.

Acknowledgements. This paper was possible through financial support from grants 1/226 2005 CNCSIS and 3701/2004-2006 MEC. We also are indebted to Mrs. Cristina Mariş of COMINEX S.A. Cluj, and geologist Adrian Minuț from Roşia Montană Gold Corporation for help with the milling facilities.

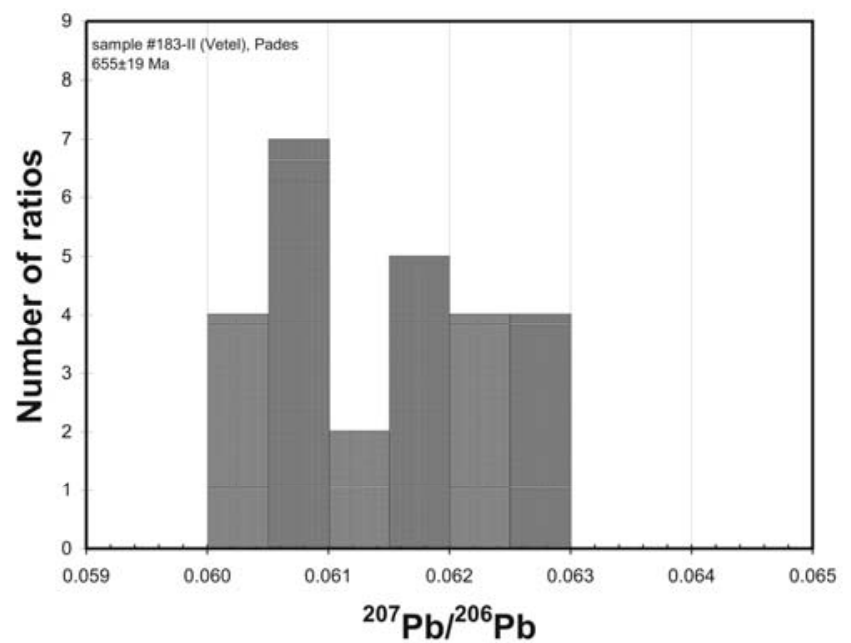

Fig. 4. Frequency diagram of one evaporated zircon grain out of sample 183-II (Vețel) which gave a mean ${ }^{207} \mathrm{~Pb} /{ }^{206} \mathrm{~Pb}$ age of $655 \pm 19 \mathrm{Ma}$.

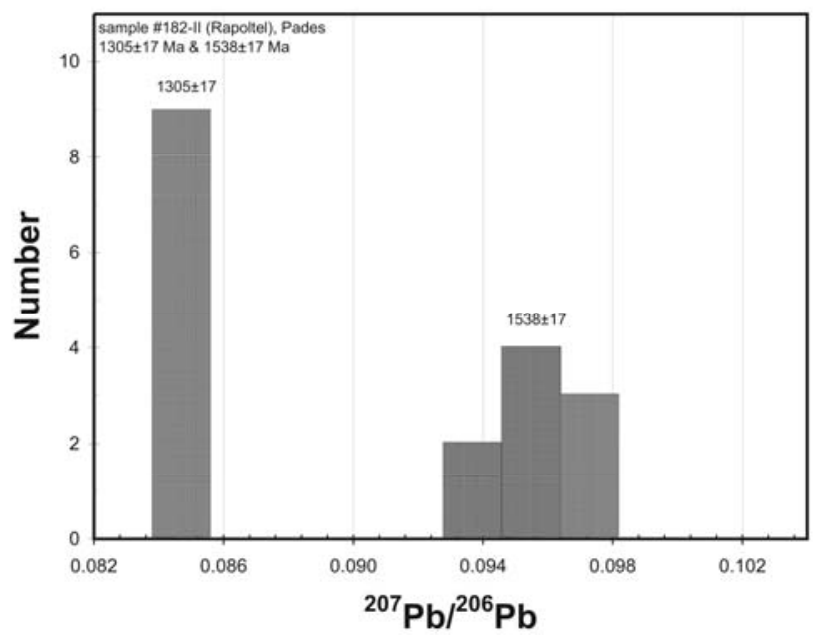

Fig. 5. Frequency diagram of one evaporated zircon grain out of sample 182-II (Rapolțel) which gave a mean ${ }^{207} \mathrm{~Pb} /{ }^{206} \mathrm{~Pb}$ age of $1305 \pm 17 \mathrm{Ma}$ and $1538 \pm 17 \mathrm{Ma}$.

\section{R E F E R E N C E S}

Balintoni, I., 1997, Geotectonica terenurilor metamorfice din România, Ed. Carpatica, Cluj Napoca, 176 pp.

Balintoni, I., Balica, C., Cliveți, M., Li-Qiu L., Hann, H.P. \& Chen, F. 2007 a, Paleogeographic and plate tectonic significance of single crystal zircon ages in a few orthogneisses and Vința granite from the Baia de Arieş sequence (Apuseni Mountains, Romania). Submitted to International Journal of Geological Science (Geol. Rund.).

Balintoni, I., Balica, C., Cliveți, M., Li-Qiu L., Hann, H.P., Chen, F. \& Ghergari, L. 2007 b, Somes terrane, a new Cadomian entity in the Apuseni Mountains, Romania (Apuseni Mountains, Romania). Studia Universitatis Babeş-Bolyai, Geologia, in review.

Balintoni, I., Balica, C., Cliveți, M., Li-Qiu Li, Hann, H.P. \& Chen, F. 2007 c, How can be interpreted the single zircon ages from Muncel granite and Henț metapelite, Paiuşeni sequence, Apuseni Mountains. Studia Universitatis Babeş-Bolyai, Geologia, in review.

Balintoni, I., Berza, T., Hann, H.P., Iancu, V., Kräutner, H.G. \& Udubaşa, G. 1989, Precambrian metamorphics 
in the South Carpathians. Guide to excursions. Institutul Geologic şi Geofizic, Bucureşti, 83 pp.

Berza, T., Iancu, V. 1994, Variscan events in the basement of the Danubian nappes (South Carpathians). Romanian Journal of Tectonics and Regional Geology, 75 (Suppl. 2): 93-103.

Bordea, J., Berbeleac, I., Borcoş, M., Mantea, G., Stancu, J. \& Rogge-Țăranu, E. 1978, Harta Geologică a României, sc. 1:50.000, Geoagiu Sheet.

Chen, F., Hegner, E., Todt, W. 2000, Zircon ages, Nd isotopic and chemical compositions of orthogneisses from the Black Forest, Germany - evidence for a Cambrian magmatic arc. International Journal of Earth Science, 88: 791-802.

Iancu, V., Balintoni, I. 1986, The mineral assemblages and parageneses in the Metamorphics of the Baia de Arieş Group - Apuseni Mountains. In Mineral Parageneses, Teophrastus Publications, Athens, pp. 473 - 493.

Kober, B. 1986, Whole-grain evaporation for ${ }^{207} \mathrm{~Pb} /{ }^{206} \mathrm{~Pb}$ age investigations on single zircons using a double-filament thermal ion source. Contribution to Mineralogy and Petrology, 93: 481-490.
Kräutner, H.G. 1996, Alpine and pre-Alpine tarranes in the Romanian South Carpathians and equivalents south of the Danube. In Terranes of Serbia (Knezevic, V., Krstic, B., Eds.), Belgrade, pp. 563-58.

Ludwig, K.R. 1988, Pbdat for MS-Dos - a computer program for IBM-PC compatibles for processing raw $\mathrm{Pb}-\mathrm{U}$-Th isotope data. U.S. Geological Survey, Openfile Report, 88-542, 1-37.

Ludwig K.R. 2001, Isoplot/Ex, rev. 2.49: A Geochronological Toolkit for Microsoft Excel. Berkeley Geochronological Center, Special Publication 1a, 58 pp.

Lupu, M., Kräutner, H.G., Țicleanu, N., Boştinescu, S., Bandrabur, T., Kräutner, F., Horvath, A.R. \& Nicolae, I. 1982, Harta Geologică a României, sc. 1:50.000, Deva Sheet.

Mureşan, M. 2003, Unitatea epimetamorfică de Poiana Ruscă (redefinire; metamorfite Caledoniene şi Varistice; linii tectonice direcționale) - Carpații Meridionali. Studii şi. Cercetări de Geologie, 48: 21-47.

Pană, D, Balintoni, I., Heaman, L. \& Creaser, R. 2002, The $\mathrm{U}-\mathrm{Pb}$ and $\mathrm{Sm}-\mathrm{Nd}$ dating of the main lithotectonic assemblages of the Eastern Carpathians, Romania. Geologica Carpatica, 53: 177-180. 